\title{
Nossas tarefas permanentes: Saúde, Democracia e Socialismo
}

José Carvalho de Noronha1,2, Lucia Souto1,3

DOI: $10.1590 / 0103-1104202112900$

ENQUANTO ESTAS LINHAS ESTÃO SENDO ESCRITAS, o Brasil atingiu 18 milhões de casos de Covid19 e acabou de romper a barreira das 500 mil mortes por essa doença. O Presidente da República faz blagues, estimula aglomerações, desincentiva a vacinação. O ano de 2020 encerrou com o País de volta ao Mapa da Fome das Nações Unidas: 60\% dos domicílios brasileiros em situação de insegurança alimentar, 15\% em situação de insegurança alimentar grave - a fome propriamente dita1. Junho de 2021, quase 15 milhões de desempregados, dos quais cerca de 3,5 milhões há mais de dois anos ${ }^{2}$. O Ministro da Economia declara que a classe média brasileira desperdiça comida e propõe que se lhes recolham os restos para alimentar a população; e quem não tem renda porque a economia parou é vagabundo, que idoso tem quer morrer, entre outras barbaridades. Além disso, mantém com vigor a política de austeridade fiscal celebrada por editoriais da grande imprensa e pelo grande capital administrado na Avenida Faria Lima em São Paulo.

Dia sim, dia também, o Presidente insulta as instituições da República, afronta a imprensa e estimula os conflitos sociais atacando direitos civis; e prossegue na sua sanha belicosa de estimular a distribuição de armas e a indisciplina nas Forças Armadas e nas forças policiais. Organiza 'motociatas' à moda de Mussolini e antecipa que não aceitará os resultados das eleições de 2022 se for derrotado.

De outra parte, embora nessa altura ainda não prosperem os pedidos de impeachment, já se observa uma crescente resistência de segmentos conservadores aos excessos do governo. Em maio e em junho, a despeito da pandemia, as ruas se encheram de manifestações populares pedindo a deposição do Presidente, vacinas, e o fim da austeridade. Discutem-se amplamente alternativas políticas e partidárias para as eleições gerais de 2022. Essa retomada requer que revisitemos nossa agenda permanente para melhor orientar nossa ação intelectual e militante na conjuntura.

Em suas últimas teses (2017-19)³, o Centro Brasileiro de Estudos de Saúde (Cebes) registrava

[...] crescente tensão entre o capitalismo e a democracia. No momento, há uma radicalização dessa tensão que surge como o maior dos desafios mediante o contexto do déficit democrático expresso pelo processo global de desorganização das democracias sociais do pós-guerra.

Em todo o mundo, os bilionários viram sua riqueza aumentar, em plena pandemia, em espantosos US\$ 3,9 trilhões entre 18 de março e 31 de dezembro de 2020. Sua riqueza total agora é de US\$11,95 trilhões, o que é equivalente ao que os governos do G20 gastaram em resposta à

\footnotetext{
${ }^{1}$ Centro Brasileiro de Estudos de Saúde (Cebes) - Rio de Janeiro (RJ), Brasil. jose.noronha@fiocruz.br

2 Fundação Oswaldo Cruz (Fiocruz), Projeto Brasil Saúde Amanhã - Rio de Janeiro (RJ), Brasil.

3 Fundação Oswaldo Cruz (Fiocruz), Escola Nacional de Saúde Pública Sergio Arouca (Ensp) - Rio de Janeiro (RJ), Brasil.
} 
pandemia em 2020. Enquanto os maiores bilionários do mundo continuam acumulando riqueza, pessoas que vivem na pobreza ficam mais pobres como resultado da crise causada pela pandemia. Estimativas recentes mostram que o número de pessoas que vivem com menos de US $\$ 5,50$ por dia poderia aumentar entre 200 milhões e 500 milhões em 2020.

No Brasil, o número de bilionários saltou $44 \%$ - de 45, em 2020, para 65, em 2021. Juntos, eles detêm US\$219,1 bilhões, aproximadamente R \$ 1,2 trilhão - quase o Produto Interno Bruto (PIB) do País. No período pandêmico, essa riqueza quase dobrou; eram US\$127,1 bilhões no ano passado, uma subida de $71 \%$.

Mercadores da morte também viram suas fortunas aumentarem. O lucro líquido das operadoras de planos de saúde cresceu 49,5\%, para R \$ 17,5 bilhões, em 2020, de acordo com dados da Agência Nacional de Saúde Suplementar (ANS). Esse mercado encerrou o ano com 47,6 milhões de usuários, o que representa uma alta de 650 mil pessoas. A receita do setor atingiu $\mathrm{R} \$ 217$ bilhões, uma alta de 4,7\%. Da lista da revista Forbes de 2021, dos 10 maiores bilionários brasileiros, três são comerciantes da saúde.

O que ressalta da crise sanitária, econômica e social no Brasil devastado pelo neoliberalismo comandado por um governo de ultradireita que conduz um Estado suicidário autoritário em movimento em torno do nada é uma realidade perturbadora. O quadro, sem chances de ser ocultado, é que a maioria da população que inspirou e é objeto do discurso e da luta por justiça e direitos humanos não é sujeito deles. A guerra civil não declarada que o País sempre viveu e naturalizou os genocídios e os massacres e a acumulação de capital garantidos pela bala e o medo, acentua Safatle ${ }^{4}$.

Como dizem Noronha et al. 5

[...] cabe então interrogar sobre o futuro mediante o desconcerto do Brasil explicito nesse momento histórico regido por um delírio de entrega ao sacrifício e incita o aplauso do povo aos seus algozes que não se importam com a morte dos outros. Quais seriam os afetos capazes de mobilizar mudanças nesse contexto em que se convoca por uma solidariedade longínqua e fragilizada e ao mesmo tempo tão requisitada pela dramaticidade desse momento de tamanha desgraça e impotência de todos?

Nenhuma medida econômica, social ou sanitária será suficiente sem a reversão do modo de ser da sociedade capitalista; o crescimento econômico como equação linear não resolve. Contudo, a crise não é apenas econômica ou sanitária, é energética, alimentar e ecológica. São os sintomas mórbidos anunciados por Gramsci do velho que ainda não pereceu na crise de hegemonia 5 .

A humanidade encontra-se na encruzilhada do socialismo ou barbárie, ou "barbárie se tivermos sorte”, como atualizou Mészáros 5 . O padrão de produção, distribuição, acumulação e consumo hoje existente nas nações europeias e norte-americanas não é reproduzível para o conjunto das pessoas do mundo. É preciso atualizar e colocar no nosso horizonte a construção de novas relações econômicas e sociais que reponham as perspectivas de mais saúde, democracia e do socialismo, para que se compreendam os movimentos táticos que devem ser empreendidos na conjuntura brasileira para a derrota do bolsonarismo e suas alianças com a burguesia retrógrada e colonizada.

O Cebes tem que aumentar sua militância nos espaços acadêmicos, políticos e nas ruas. Desde a recomposição da representação da chamada 'comunidade científica' no Conselho Nacional de Saúde (CNS), solidificou sua ação coordenada com a Associação Brasileira de Saúde Coletiva (Abrasco), Rede Unida, Sociedade Brasileira de Bioética e Associação Brasileira de Economia da Saúde (Abres). Teve um papel destacado, com essas entidades, na elaboração, em 2020, do Plano Nacional de Enfrentamento da Covid entregue às autoridades sanitárias e ao Congresso Nacional, 
além de ampla divulgação pública, consolidada na criação da Frente pela Vida. Teve um protagonismo relevante no CNS na luta pelo financiamento da saúde e pela revogação da EC 95.

Com os movimentos populares, participa da Frente Brasil Popular e da Frente Povo Sem Medo. Desde dezembro de 2020, iniciou uma séria de debates virtuais com lideranças políticas, sanitárias e populares para a apoiar a luta quotidiana para a derrota do governo fascista e neoliberal que assombra o País.

Cebes na luta sempre! Saúde, Democracia e Socialismo!

\section{Colaboradores}

Noronha JC (0000-0003-0895-6245)* e Souto L (0000-0003-2270-8424)* contribuíram igualmente para a elaboração do manuscrito.

\section{Referências}

1. Galindo E, Teixeira MA, Araújo M, et al. Efeitos da pandemia na alimentação e na situação da segurança alimentar no Brasil. Working Paper Series. 2021 [acesso em 2021 jun 18]; (4). Disponível em: https:// www.lai.fu-berlin.de/en/forschung/food-for-justice/publications/Publikationsliste_Working-PaperSeries/Working-Paper-4/index.html.

2. Instituto Brasileiro de Geografia e Estatística. Pesquisa Nacional por Amostra de Domicílios Contínua Primeiro Trimestre de 2021. Rio de Janeiro: IBGE; 2021. [acesso em 2021 jun 18]. Disponível em https://biblioteca.ibge.gov.br/visualizacao/periodicos/2421/pnact_2021_1tri.pdf.

3. Centro Brasileiro de Estudos de Saúde. Cebes na luta: transformar e radicalizar a Democracia para assegurar Direitos Sociais e Saúde. Tese do Cebes 2017-2019. Rio de Janeiro: Cebes; 2018. [acesso em
2021 jun 22]. Disponível em http://cebes.org.br/ site/wp-content/uploads/2018/07/Tese2017-19_ Cebes.pdf.

4. Safatle V. Bem-vindo ao Estado suicidário. São Paulo: N-1 Edições; 2020. [acesso em 2021 jun 16]. Disponível em https://www.n-ledicoes.org/ textos/23.

5. Noronha JC, Castro L, Noronha GS, et al. A humanidade na encruzilhada: a luta contra a barbárie no pós-covid - reflexões desde o Brasil. In: Tetelboin CH, Iturrieta DH, Schor-Landman C, coordenadoras. América Latina: Sociedad, política y salud en tiempos de pandemia. Buenos Aires: CLACSO; 2021. p. 45-70. [acesso em 2021 mar 22]. Disponível em http://biblioteca.clacso.edu.ar/clacso/gt/20210312065632/America-Latina-Sociedadpolitica-y-salud.pdf.
*Orcid (Open Researcher and Contributor ID). 